\title{
Nitrification and dissimilatory ammonium production and their effects on nitrogen flux over the sediment-water interface in bioturbated coastal sediments
}

\author{
Viveka Enoksson \& Matts-Ola Samuelsson \\ Department of Marine Microbiology, University of Göteborg, Carl Skottsbergs Gata 22, S-413 19 Göteborg, Sweden
}

\begin{abstract}
Nitrification and dissimilatory reduction of nitrate to ammonium were measured concomitantly with nitrogen release from marine coastal sediment samples from 2 fjord sill stations. Dissimilatory ammonium production (DAP) and nitrification were measured using core injections of ${ }^{15} \mathrm{NO}_{3}^{-}$and $\mathrm{H}^{14} \mathrm{CO}_{3}^{-}$, respectively. DAP was detected in all segments of the cores by tracing ${ }^{15} \mathrm{NH}_{4}^{+}$ evolved from the added ${ }^{15} \mathrm{NO}_{3}^{-}$. ${ }^{15} \mathrm{NH}_{4}^{+}$recovery increased with increasing core depth, ranging from 1.6 to $10 \%$ for Stn $\mathrm{H}$ and from 0.3 to $2.9 \%$ for Stn L. Nitrification activity at Stn L was in the order of 10 $\mathrm{nmol} \mathrm{cm}^{-3} \mathrm{~h}^{-1}$ in the upper $2 \mathrm{~cm}$ but was not demonstrated in deeper strata. Consequently, DAP was most pronounced in the upper few centimeters although it was anticipated that more than $97 \%$ of the nitrate produced was denitrified. Mean fluxes of ammonium out of the sediment were 24 and $12 \mu \mathrm{mol}$ $\mathrm{m}^{-2} \mathrm{~h}^{-1}$ for Stns $\mathrm{H}$ and L, respectively, and corresponding nitrate fluxes were 2 and $-24 \mu \mathrm{mol} \mathrm{m}^{-2} \mathrm{~h}^{-1}$. The sum of ammonium and nitrate release in the individual cores did not reach the rates expected from their oxygen consumption rates, which implies that inorganic nitrogen was lost, probably due to coupled nitrification and denitrification. This estimated loss was about half of the obtained nitrification rate at Stn L. Furthermore, the estimated loss was larger in cores with a rich macrofauna and especially with high numbers of Amphiura spp. (brittlestars). It is suggested that these animals stimulate both nitrification and dissimilatory nitrate reduction.
\end{abstract}

\section{INTRODUCTION}

The role of marine sediments as a source or sink for nitrogen in the overlying water is governed by the relative rates of ammonium, nitrate and nitrogen gas production. The strictly aerobic nitrification occurs in the upper few centimeters (Henriksen et al. 1981), and a sub-surface peak of nitrate due to nitrification is often detected even though oxygen is depleted a few millimeters away from the sediment-water interface in coastal sediments (Revsbech et al. 1980). Nitrification and the anaerobic denitrification have also been shown to be coupled within the same stratum (e.g. Jenkins \& Kemp 1984). These workers found that $99 \%$ of added ${ }^{15} \mathrm{~N}$-ammonium was converted to nitrogen gas. As both processes may be greatly enhanced by bioturbation (Henriksen et al. 1983), benthic infauna may alter the release of gaseous nitrogen relative to the release of inorganic nitrogen compounds from sediments. The mechanisms of bioturbation and its effects on sediment-water exchange have been extensively described by Aller (1980). The main characteristics are increased area of aerobic-anaerobic interfaces and of steep solute gradients. Furthermore, denitrification can occur within fecal pellets of benthic polychaetes at high oxygen concentrations (Sayama \& Kurihara 1983).

Several authors (Koike \& Hattori 1978, Sørensen 1978) have stressed that dissimilatory nitrate reduction to ammonium, referred to as dissimilatory ammonium production (DAP), is an important sink for nitrate and that DAP competes with denitrification for nitrate in the sediment. A more reduced sediment, especially when combined with a high organic content, seems to favour DAP (Buresh \& Patrick 1981, Kaspar 1983). The bacterial interactions appeared more complex when it was found that the dissimilatory ammonium producer 
Pseudomonas putrefaciens was also able to evolve nitrogen gas under certain conditions (Samuelsson 1985).

Evidently, the fluxes of oxygen and nitrogen across the sediment-water interface reflect not only pool sizes but also transport mechanisms across the interface. Unlike oxygen consumption, net fluxes of inorganic nitrogen (IN) from oxic coastal sediments are highly variable in time and space and may even be reversed (Enoksson \& Rüdén-Berg 1983). This investigation is focused on the interrelations between nitrification and nitrate reduction, in particular the formation of ammonium via dissimilatory reduction. In addition, we investigated nitrogen release from the sediment in relation to oxygen consumption (IN/ $-\mathrm{O}_{2}$ ) and macroinfauna. Through compilation of these data, it was feasible to make approximate calculations of in situ rates of denitrification and dissimilatory ammonium production.

\section{MATERLALS AND METHODS}

Samples. Sediment samples were taken in the Gullmar fjord which has a $30 \mathrm{~m}$ deep sill at the entrance, where bottom water is well oxygenated throughout the year. All samples were taken in September 1981 at the 2 stations $\mathrm{H}\left(58^{\circ} 15.8^{\prime} \mathrm{N}, 11^{\circ} 28.7^{\prime} \mathrm{E}\right)$ and $\mathrm{L}\left(58^{\circ} 15.3^{\prime} \mathrm{N}\right.$, $\left.11^{\circ} 27.3^{\prime} \mathrm{E}\right)$ located on the sill. Amphiura filiformis, (mainly a filter feeder) and Amphiura chiaeij (mainly a deposit feeder) were the dominating macro-fauna species, estimated by weight, at both stations (A. Josefson pers. comm).

Water samples for in situ oxygen and nutrient analyses were taken with a $5 \mathrm{l}$ sampler that closed on touching the bottom. A 301 Niskin sampler was used to collect bottom water for the flux measurements. Undisturbed sediment was collected using a $30 \times 30 \mathrm{~cm}$ box-core sampler and cores were then subsampled with acrylic plexiglass tubes for analyses of in situ concentrations, for sediment-water flux studies and for isotope studies. Eh was measured in separate, $5 \mathrm{~cm}$ I.D. cores with a fine tip platinum electrode and a calomel reference electrode (Radiometer, Copenhagen). Gentle sideways movements of the platinum electrode during horizontal insertion yielded a stable recording within about 1 min. At both stations, the cores were brown at the surface $(0$ to $2 \mathrm{~cm}$ ) and grey below, and consisted of silt and fine sand. No smell of hydrogen sulfide was detected during sampling.

Chemical analyses. The $\mathrm{O}_{2}$ concentration in the bottom water in situ was measured by Winkler titration. A Clark type electrode (Rank Brothers, Cambridge, UK) was used for the discrete $\mathrm{O}_{2}$ samples (5 or $10 \mathrm{ml}$ ) taken during the flux determinations. $\mathrm{NO}_{2}^{-}$and
$\mathrm{NO}_{3}^{-}$were analysed with a Technicon Auto-Analyzer according to Armstrong et al. (1967). After filtration (GF/F; Whatman glass fiber filters), total dissolved nitrogen (dissolved organic $N, D O N$, after subtracting IN) was analysed on duplicate $4 \mathrm{ml}$ samples using UV oxidation (Armstrong et al. 1966) with $0.2 \mathrm{ml}$ of an oxidizing reagent (Valderrama 1981) (35\% v/v of $1 \mathrm{M}$ $\mathrm{NaOH}, 5 \% \mathrm{w} / \mathrm{v}$ of $\mathrm{K}_{2} \mathrm{~S}_{2} \mathrm{O}_{8}$ and $3 \% \mathrm{w} / \mathrm{v}$ of $\mathrm{H}_{3} \mathrm{BO}_{3}$ ). The $\mathrm{NH}_{4}^{+}$was analysed by the indophenol blue method according to Koroleff (1976). Exchangeable $\mathrm{NH}_{4}^{+}$was extracted in a $1: 1$ suspension of sediment and $0.5 \mathrm{M}$ $\mathrm{KCl}$ for $1 \mathrm{~h}$ in an ice bath. $\mathrm{NH}_{4}^{+}$was analysed on the supernatant after centrifugation and filtration. Total carbon and nitrogen content was analysed using a Carlo-Erba 1106 CHN analyser. Inorganic carbon was removed from weighed samples in $\mathrm{Ag}$ capsules by treatment with $\mathrm{HCl}$ fumes for 36 to $48 \mathrm{~h}$ according to Hedges \& Stern (1984).

Flux measurements. Subcores $(8 \mathrm{~cm}$ I.D.) were incubated at $10^{\circ} \mathrm{C}$ in a water bath. The gently stirred water phase (ca $500 \mathrm{ml}$ ) above the sediment was continuously exchanged at approximately $40 \mathrm{ml} \mathrm{h}^{-1}$ with bottom water from the same site as the sediment, and then kept in the same water bath. This flow-through system was an improvement of that described by Enoksson \& Rüdén-Berg (1983), in that the water in the reservoir was at the same level as the water in the sediment tubes. This ensured atmospheric pressure inside the tubes which was essential for the measurement of gas flux. Analyses of solutes were made on the reservoir and on the effluent from the sediment cores. Discrete $\mathrm{O}_{2}$ samples were taken with a $5 \mathrm{ml}$ syringe through septa in the lids. The reported results were obtained during the first $2 \mathrm{~d}$ of incubation and flux rate determinations were performed utilizing 3 to 6 individual analyses. The flux of DON was, however, measured using 7 cores from Stn $\mathrm{H}$ during Days 2 to 5 ( 3 determinations). The macrofauna in each core was collected onto $1 \mathrm{~mm}$ mesh sieves at the end of the experiments.

Rate measurements. The core-injection technique (Jørgensen 1978) was used for measuring the rate of nitrification and DAP. Subcores $(20 \mathrm{~cm}$ deep and $2.6 \mathrm{~cm}$ diameter) were placed in a water bath at $10^{\circ} \mathrm{C}$ and left for $1 \mathrm{~h}$ after collection in order to minimize the effect of disturbance. Thereafter, the overlying water was removed and the inhibitor or isotope-labelled substrate injected (see below). The subsequent incubations were stopped by freezing the sediment cores in a mixture of dry ice and ethanol. Within 1 mo of storage at $-20^{\circ} \mathrm{C}$, the frozen cores were sectioned and analysed.

Nitrification. The ${ }^{14} \mathrm{C}$-bicarbonate incorporation method of Billen (1976) was modified for the direct injection technique. An ethanol solution containing $\mathrm{N}$ - 
serve $(5 \times 10 \mu \mathrm{l}$, 2-chloro-6-trichloromethylpyridine; Dow Chemical Co., King's Lynn, UK) was injected into half the number of cores at $0.5,1.5,3.5,6.5$ and $10.5 \mathrm{~cm}$ depth at a final concentration of $10 \mu \mathrm{g} \mathrm{cm}^{-3}$. Ethanol alone was added in the same way to the remaining replicates. After approximately $2 \mathrm{~h}, 10 \mu \mathrm{l}$ of a $\mathrm{H}^{14} \mathrm{CO}_{3}^{-}$ solution (about $4 \mu \mathrm{Ci}$ ) was added at the same depths as the $\mathrm{N}$-serve to all the cores ( 8 per station) which were then incubated for $4.3 \mathrm{~h}$. Prior to the ${ }^{14} \mathrm{C}$ determination, 1 to $1.5 \mathrm{~cm}$ core sections were centrifuged at $8000 \mathrm{rpm}$ at $5^{\circ} \mathrm{C}$ for $10 \mathrm{~min}$. The supernatant was pressure filtered $(\mathrm{GF} / \mathrm{F} ; 25 \mathrm{~mm})$ and the carbonate alkalinity was determined according to Strickland \& Parsons (1972), using $1 \mathrm{ml}$ of the filtrate. No detectable change in alkalinity occurred due to freezing. The following procedure for the transfer of labelled organic $\mathrm{C}$ into $\mathrm{CO}_{2}$ was essentially as described by Smith et ai. (1972), modified by L. Rüdén (pers. comm.). The sediment pellet was resuspended in $6 \mathrm{ml}$ of the dilute sulfuric $\operatorname{acid}\left(8.7 \% \mathrm{v} / \mathrm{v}\right.$ of conc. $\left.\mathrm{H}_{2} \mathrm{SO}_{4}\right)$ containing $14 \%(\mathrm{w} / \mathrm{v})$ of $\mathrm{FeSO}_{4} \cdot 7 \mathrm{H}_{2} \mathrm{O}$. An aliquot (ca $3 \mathrm{ml}$ ) of the suspension was transferred, during vigorous stirring, to a $50 \mathrm{ml}$ serum bottle, boiled and allowed to cool. Any remaining $\mathrm{CO}_{2}$ was stripped off by bubbling air into the bottle for $30 \mathrm{~s}$. This treatment for removal of unincorporated $\mathrm{H}^{14} \mathrm{CO}_{3}^{-}$was shown to be $100 \%$ efficient by adding the tracer to autoclaved sediment which was processed as described for the samples. Subsequently $3.4 \mathrm{ml}$ of a concentrated acid mixture $\left(1 \% \mathrm{w} / \mathrm{v}\right.$ of $\mathrm{Ag}_{2} \mathrm{SO}_{4}$ in conc. $\mathrm{H}_{2} \mathrm{SO}_{4}$ and conc. $\mathrm{H}_{3} \mathrm{PO}_{4}$ in proportions $3: 2$ ) was added, immediately followed by $1.4 \mathrm{~g}$ of $\mathrm{K}_{2} \mathrm{Cr}_{2} \mathrm{O}_{7}$ (solid). The bottle was quickly sealed with a gas-tight butyl rubber stopper and autoclaved for $1 \mathrm{~h}$ at $120^{\circ} \mathrm{C}$ in order to oxidize the organic carbon to $\mathrm{CO}_{2}(\mathrm{~g})$. The gas phase of the sample bottle was driven off with $\mathrm{CO}_{2}$-free air for $5 \mathrm{~min}$ and the $\mathrm{CO}_{2}$ collected in Oxifluor scintillation cocktail (New England Nuclear Corp., Boston, Massachusetts, USA). Potentially quenching vapours of chromium were trapped in a wash bottle with acidified ethanol before the gas reached the cocktail. Recovery was tested by adding $\mathrm{H}^{14} \mathrm{CO}_{3}^{-}$to autoclaved sediment (omitting the dilute acid treatment) and was found to be virtually $100 \%$. The ${ }^{14} \mathrm{C}$-activity of the cocktail was counted in a Packard Tri Carb liquid scintillation counter. The counts were corrected for quenching using the external standard ratio and the counting efficiency for a $\mathrm{H}^{14} \mathrm{CO}_{3}^{-}$standard in Oxifluor that had been quenched with various amounts of chromium vapour. The quenching noted in the samples was comparable to that noted for the pure Oxifluor. Carbonate uptake was calculated using the carbonate alkalinity for each individual sample. The $\mathrm{N} / \mathrm{C}$ conversion factor of 8.3 (Billen 1976) was used to estimate the nitrification rate from the $\mathrm{N}$-serve sensitive carbonate uptake.
Dissimilatory ammonium production. A $40 \mu \mathrm{l}$ volume of a $\mathrm{K}^{15} \mathrm{NO}_{3}$ solution (97 atom\% ${ }^{15} \mathrm{~N}$, Prochem B.O.C. Ltd., London) in synthetic seawater (Strickland \& Parsons 1972) was injected into sediment cores at each $\mathrm{cm}$ down to $10 \mathrm{~cm}$ depth. Two different concentrations of ${ }^{15} \mathrm{NO}_{3}^{-}$for $\mathrm{Stn} \mathrm{H}$, giving final concentrations of 270 and $27 \mathrm{nmol} \mathrm{cm}{ }^{-3}$, were used while only the high concentration was used for $\mathrm{Stn} \mathrm{L}$. The cores were incubated for 6,12 or $24 \mathrm{~h}$ ( 4 cores for each time). Three incubated, frozen cores were sectioned to a depth of $10 \mathrm{~cm}$ into 1 or $2 \mathrm{~cm}$ slices which were transferred to centrifuge tubes. Exchangeable $\mathrm{NH}_{4}^{+}$was extracted for up to $1 \mathrm{~h}$ in an ice bath using $1.5 \mathrm{ml} 4 \mathrm{M} \mathrm{KCl}$. The sediment was then centrifuged and $\mathrm{NH}_{4}^{+}$determined in the supernatant as described. For the isotope ratio analysis, $3 \mathrm{ml}$ of the supernatant was transferred to a $24 \mathrm{ml}$ vial. The $\mathrm{NH}_{4}^{+}$was concentrated into a capillary as described by Blackburn (1979). The capillary was then treated according to Samuelsson \& Rönner (1982) and the ${ }^{15} \mathrm{~N} /{ }^{14} \mathrm{~N}$ ratio was determined in a Statron NOI-5 emission spectrometer. The dry weight of the sediment was recorded after $24 \mathrm{~h}$ at $105^{\circ} \mathrm{C}$. The fourth core, with added ${ }^{15} \mathrm{NO}_{3}^{-}$, was used for determining the $\mathrm{NO}_{2}^{-}$and $\mathrm{NO}_{3}^{-}$concentrations (as described above) in the pore water after incubation.

\section{RESULTS}

\section{In situ conditions}

Oxygen concentrations in the bottom water were 160 and $180 \mu \mathrm{mol} \mathrm{l}^{-1}$ (3.5 and $4.0 \mathrm{ml} \mathrm{l}^{-1}$ ) at Stns $\mathrm{L}$ and $\mathrm{H}$ respectively. Redox potential (Eh) was approximately $175 \mathrm{mV}$ at Stn L and $100 \mathrm{mV}$ lower at Stn $\mathrm{H}$ in the upper $1 \mathrm{~cm}$, decreasing gradually with depth at both stations. In situ concentrations of nitrate, nitrite and ammonium in the bottom and pore-water at Stns $\mathrm{H}$ and $\mathrm{L}$ are shown in Fig. $1 \mathrm{~A}$ to $\mathrm{C}$. Total ammonium levels were similar for the 2 stations (Fig. 1A), exhibiting a sharp gradient near the interface. At depths below $3 \mathrm{~cm}$, concentrations of 100 to $200 \mathrm{nmol} \mathrm{\textrm {cm } ^ { - 3 }}$ were noted. Although nitrate concentrations were higher at Stn L, the profiles (Fig. 1B) were similar at the 2 stations with a maximum at 0 to $2 \mathrm{~cm}$ at $S \operatorname{stn} \mathrm{L}$ and at 0 to $1 \mathrm{~cm}$ at Stn H. Nitrite profiles (Fig. 1C) showed a similar pattern as for nitrate but concentrations were about one order of magnitude lower.

Organic carbon content and organic C/total $\mathrm{N}$ atomic ratio $(\mathrm{C} / \mathrm{N})$, at the 2 stations are presented in Table 1. Mean organic carbon content in the upper $10 \mathrm{~cm}$ was $2.6 \mathrm{mmol} \mathrm{g}^{-1}(3.1 \% \mathrm{w} / \mathrm{w})$ at $\mathrm{Stn} \mathrm{L}$ and $1.4 \mathrm{mmol} \mathrm{g} \mathrm{g}^{-1}(1.7 \%)$ at $\mathrm{Stn} \mathrm{H}$. Values varied insig- 

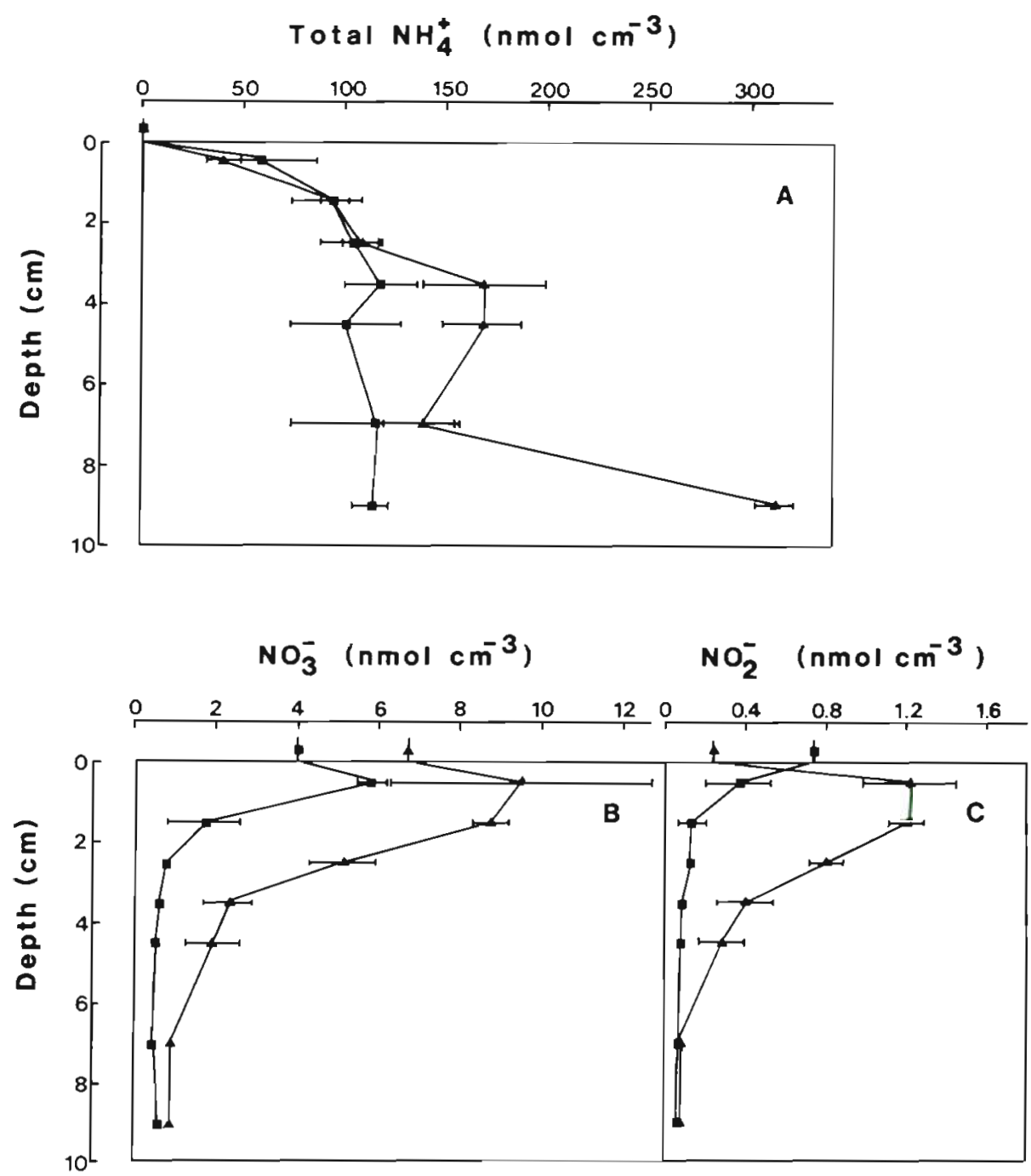

Fig. 1. In situ concentrations of $(\mathrm{A})$ total $\mathrm{NH}_{4}^{+}$(per $\mathrm{cm}^{3}$ sediment after $\mathrm{KCl}$ treatment); (B) pore-water $\mathrm{NO}_{3}^{-}$; and $(\mathrm{C}) \mathrm{NO}_{2}^{-}$at Stns $\mathrm{H}$ and $\mathrm{L}(\mathbf{4})$ nificantly with depth. The corresponding mean $\mathrm{C} / \mathrm{N}$ ratios showed similar values, 10.9 at $S t n H$ and 10.2 at Stn $\mathrm{L}$.

\section{Sediment-water flux}

The sediment-water flux and macro-fauna data are summarized in Table 2. There were no obvious differences in oxygen consumption rates between cores sampled at the 2 stations. The oxygen concentrations used above the cores were near to in situ concentrations except in 2 cores from Stn $\mathrm{H}$ where oxygen was allowed to drop to 42 and $69 \mu \mathrm{M}$ within $1 \mathrm{~d}$. Ammonium was the only fraction of IN that was released at significant rates from the sediment, 12 and $24 \mu \mathrm{mol} \mathrm{m}^{-2} \mathrm{~h}^{-1}$ for Stns $\mathrm{L}$ and $\mathrm{H}$ respectively. Because of a considerable nitrate uptake $(24 \mu \mathrm{mol}$ $\mathrm{m}^{-2} \mathrm{~h}^{-1}$ ), the Stn $\mathrm{L}$ sediment acted as a sink for IN. There was a slow efflux of nitrate from Stn $\mathrm{H}(2 \mu \mathrm{mol}$ $\mathrm{m}^{-2} \mathrm{~h}^{-1}$ ). The leakage of DON at Stn H (Days 2 to 5 )
Table 1. Depth distribution of organic carbon and atomic $\mathrm{C} / \mathrm{N}$ ratio in sediments collected in Sep from Stns $L$ and $H$ at $30 \mathrm{~m}$ depth in the Gullmar fjord, western Sweden

\begin{tabular}{|c|c|c|c|c|}
\hline \multirow{2}{*}{$\begin{array}{c}\text { Depth } \\
\text { (cm) }\end{array}$} & \multicolumn{2}{|c|}{ Org. C mmol g ${ }^{-1}$} & \multicolumn{2}{|c|}{$\mathrm{C} / \mathrm{N}$ atomic ratio } \\
\hline & $\mathrm{L}$ & $H$ & $\mathrm{~L}$ & $\mathrm{H}$ \\
\hline $0-1$ & 2.53 & 1.27 & 10.3 & 10.8 \\
\hline $1-2$ & 2.88 & 1.35 & 9.7 & 10.9 \\
\hline $2-3$ & 2.63 & 1.40 & 10.0 & 10.8 \\
\hline $3-4$ & 2.56 & 1.45 & 10.2 & 11.1 \\
\hline $4-5$ & 2.60 & - & 10.2 & - \\
\hline $6-8$ & 2.51 & 1.56 & 10.2 & 11.0 \\
\hline $8-10$ & 2.47 & 1.51 & 10.5 & 10.6 \\
\hline
\end{tabular}

was 23.9 (SD 3.9) $\mu \mathrm{mol} \mathrm{m} \mathrm{m}^{-2} \mathrm{~h}^{-1}$, showing no significant relation with any of the measured parameters. Amphiura spp. ( $70 \%$ A. filiformis) dominated the larger macro-fauna both by number and biomass, Stn L being the most densely populated. Polychaete burrows 
Table 2. Oxygen concentrations in the overlying water, benthic oxygen consumption, nitrate-, ammonium- and IN- (inorganic nitrogen) flux rates over the interface in $2 \mathrm{~d}$ flow-through incubations of $\mathrm{Stn} \mathrm{L}$ and $\mathrm{H}$ sediments and macrofauna biomass and abundance, expressed as the mean, min. and max. of incubated cores

\begin{tabular}{|c|c|c|c|c|c|}
\hline \multirow[t]{2}{*}{ Parameter } & \multirow[t]{2}{*}{ Unit } & \multicolumn{2}{|c|}{ Station L (4 cores) } & \multicolumn{2}{|c|}{ Station H (11 cores) } \\
\hline & & $\bar{X}$ & (Min.-Max.) & $\overline{\mathrm{X}}$ & (Min.-Max.) \\
\hline Oxygen & $\mu \mathrm{M}$ & 187 & $(174-198)$ & 171 & $(68-219)$ \\
\hline Oxygen & $\mu \mathrm{mol} \mathrm{m} \mathrm{m}^{-2} \mathrm{~h}^{-1}$ & 910 & $(840-960)$ & 822 & $(610-1230)$ \\
\hline Nitrate & umol m $\mathrm{m}^{-2} \mathrm{~h}^{-1}$ & -24 & $(-34--12)$ & 2 & $(-8-11)$ \\
\hline Ammonium & $\mu \mathrm{mol} \mathrm{m} \mathrm{m}^{-2} \mathrm{~h}^{-1}$ & 12 & $(6-19)$ & 24 & $(-4-55)$ \\
\hline IN & $\mu \mathrm{mol} \mathrm{m} \mathrm{m}^{-2} \mathrm{~h}^{-1}$ & -12 & $(-28-6.2)$ & 28 & $\left(\begin{array}{ll}-7-62)\end{array}\right.$ \\
\hline Biomass ${ }^{*}$ & $\mathrm{~g} \mathrm{~m}^{-2}$ & 250 & $(214-318)$ & 230 & $(50-890)$ \\
\hline \multicolumn{6}{|l|}{ Abundance } \\
\hline Amphiura & No. $\mathrm{m}^{-2}$ & 1050 & $(600-1800)$ & 580 & $(200-1000)$ \\
\hline Worms" " & No. $\mathrm{m}^{-2}$ & 400 & & 130 & \\
\hline
\end{tabular}

were observed in almost all cores, down to at least $8 \mathrm{~cm}$ core depth, at the end of the incubations.

Rates of ammonium release from the various cores were not or only weakly related to Amphiura spp. abundance ( $r=0.38$ ), macro-fauna biomass ( $r=0.19$ ) or benthic oxygen consumption $(r=0.10)$. Nitrate release by the sediment was observed in 6 out of 15 cores, all with 3 or fewer individuals of Amphiura spp. while nitrate uptake took place in cores containing 3 to 9 Amphiura spp. Nitrate flux was not significantly related to nitrate concentration in the water-phase $(\mathrm{r}=$ 0.33). The net flux rates of inorganic nitrogen versus the rates of oxygen consumption $\left(\mathrm{IN} /-\mathrm{O}_{2}\right)$ are shown in Fig. 2. Cores were grouped mainly on the basis of the fauna. However 2 cores were assigned to a separate group (Group a) because of their low oxygen concentration in the overlying water. Group (b) refers to the cores in which macro-fauna biomass was less than $1 \mathrm{~g}$ per core and that contained 3 or fewer Amphiura spp. The remaining cores with a richer fauna were assigned to Group (c) which includes the 4 cores from Stn L. For comparison, the $\mathrm{IN} /-\mathrm{O}_{2}$ ratio of $1: 10.5$ is given as the dashed line. This ratio is derived from the mean $\mathrm{C} / \mathrm{N}$ ratio of 10.5 in the upper $1 \mathrm{~cm}$ of the sediment (Table 1), according to Redfield et al. (1963). The IN/ $-\mathrm{O}_{2}$ ratio was lower than $1: 10.5$ in all cores, even though the discrepancy was only approximately $20 \mu \mathrm{mol} \mathrm{m} \mathrm{m}^{-2} \mathrm{~h}^{-1}$ at low oxygen concentrations (Group a) and about $25 \mu \mathrm{mol} \mathrm{m} \mathrm{m}^{-2} \mathrm{~h}^{-1}$ in 2 cores with high oxygen consumption rate and poor fauna. Generally
Fig. 2. Net flux of IN (inorganic nitrogen) versus benthic oxygen consumption. Mean values of 2 determinations for each core, from Stns $L(\nabla)$ and $H(\triangle)$. Small and large triangles refer to a macro-fauna biomass of less or more than $1 \mathrm{~g}$ per core, respectively, and ticks refer to no. of Amphiura spp. per core. Group (a): low oxygen concentration $(<80 \mu \mathrm{M})$; (b): number of $A m$ phiura spp. $\leq 3$ and biomass $<1 \mathrm{~g}$; (c): Amphiura spp. $\geq 3$. Dashed line represents the organic $\mathrm{C} / \mathrm{N}$ ratio of the sediment (see text)

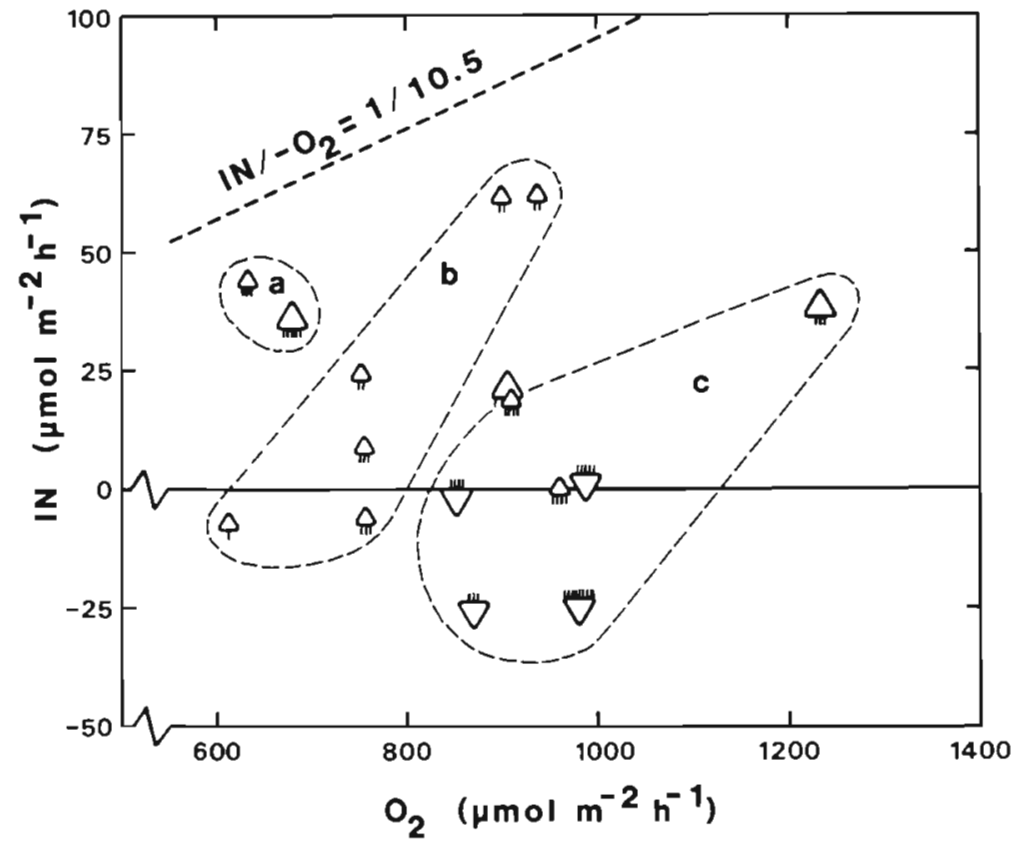


the IN flux departed the most from the expected 'Redfield relation' in cores with the richest fauna. The mean discrepancy for the Group (b) cores was 51 (SD 22) umol m $\mathrm{m}^{-2} \mathrm{~h}^{-1}$, while almost twice as much, 92 (SD 17) umol $\mathrm{m}^{-2} \mathrm{~h}^{-1}$, appeared to be 'missing' in Group (c) cores with the richest fauna. The core with the largest number of Amphiura spp, removed IN at a considerable rate from the water $\left(25.5 \mu \mathrm{mol} \mathrm{m} \mathrm{m}^{-2} \mathrm{~h}^{-1}\right)$, although a release of approximately $93 \mu \mathrm{mol} \mathrm{m} \mathrm{m}^{-2} \mathrm{~h}^{-1}$ would have been expected from the oxygen consumption.

\section{Nitrification}

In Fig. 3 bicarbonate incorporation rates at Stn $\mathrm{L}$ are plotted against depth with and without added $\mathrm{N}$-serve. At 0.5 and $1.5 \mathrm{~cm}$ depth, the rates were significantly lower when the $\mathrm{N}$-serve was added to the cores. The estimated nitrate production rate was $15 \mathrm{nmol}$ $\mathrm{cm}^{-3} \mathrm{~h}^{-1}$ in the upper $1 \mathrm{~cm}$ (insert in Fig. 3). No significant inhibition of bicarbonate incorporation due to the $\mathrm{N}$-serve was demonstrated in the third section or deeper and, although the exact depth limit for the process could not be specified, we have only used the activity in the upper 2 sections for further estimations. The nitrification rate per unit area was thus estimated to be $250 \mu \mathrm{mol} \mathrm{m}{ }^{-2} \mathrm{~h}^{-1}$. The obtained ${ }^{14} \mathrm{C}$-bicarbonate incorporation was too variable at Stn $\mathrm{H}$; no estimate of nitrification could be given for this station.

\section{Dissimilatory ammonium production}

DAP capacities (Fig. 4) increased with depth at both stations for the $6 \mathrm{~h}$ incubations; at Stn $\mathrm{H}$ from $4.2 \mathrm{nmol}$

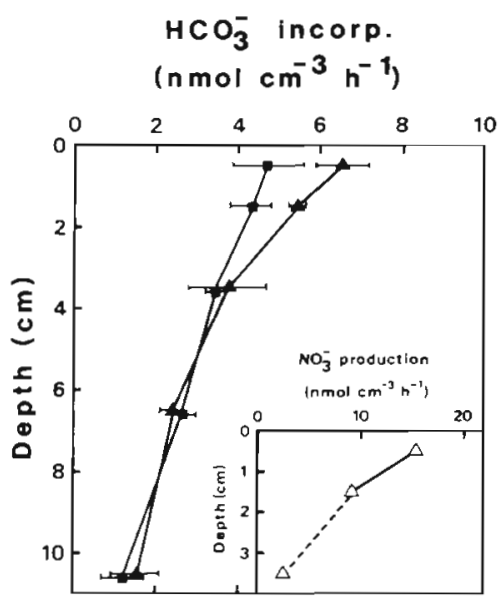

Fig. 3. Rates of ${ }^{14} \mathrm{C}$-bicarbonate incorporation at various depths during $4.3 \mathrm{~h}$ incubation of undisturbed sediment cores from Stn L. (4) Total rate; (घ) rate with added nitrification inhibitor ( $\mathrm{N}$-serve). Horizontal bars show standard deviation of the 4 replicates. In the insert, the corresponding calculated $(\mathrm{C} / \mathrm{N}=8.3)$ nitrification rates have been plotted against depth

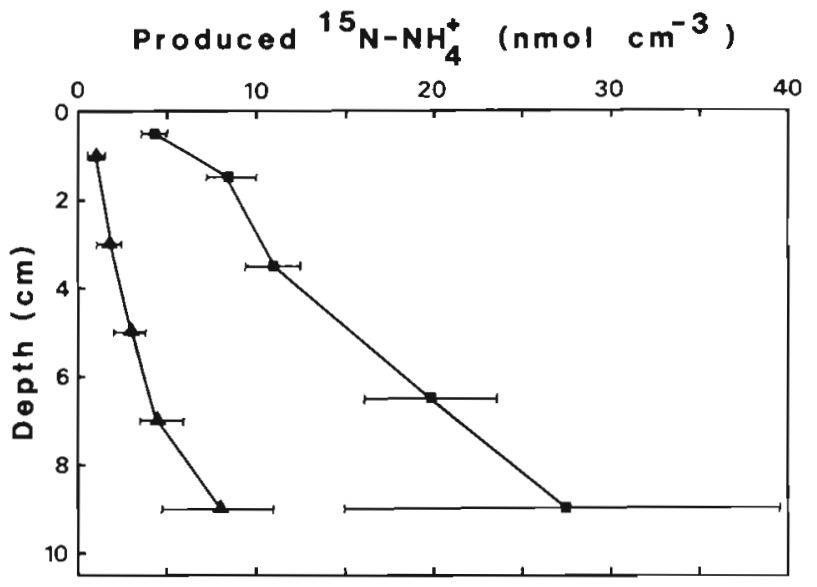

Fig. 4. Production of ${ }^{15} \mathrm{~N}-\mathrm{NH}_{4}^{+}$from added ${ }^{15} \mathrm{~N}-\mathrm{NO}{ }_{3}^{-}(270 \mathrm{nmol}$ $\mathrm{cm}^{-3}$ ) in undisturbed sediment cores from Stn L ( $\left.\Delta\right)$ and $\mathrm{H}(\boldsymbol{\bullet})$ at various depths. Incubation time was $6 \mathrm{~h}$; data are presented as mean, minimum and maximum values for 3 replicate cores

$\mathrm{cm}^{-3}(0$ to $1 \mathrm{~cm})$ to $27.6 \mathrm{nmol} \mathrm{cm} \mathrm{cm}^{-3}(8$ to $10 \mathrm{~cm})$ and at Stn $\mathrm{L}$ from 0.9 to $7.8 \mathrm{nmol} \mathrm{\textrm {cm } ^ { - 3 }}$ over the same depth range. As excess nitrate was consumed after $6 \mathrm{~h}$, DAP capacities obtained from the longer incubations were considered less representative. Because of the rapid nitrate consumption, no significant dilution of the isotope due to nitrification could have taken place. The mean fraction of ${ }^{15} \mathrm{~N}$ recovered as ${ }^{15} \mathrm{~N}$-ammonium at 0 to $10 \mathrm{~cm}$ for the $6 \mathrm{~h}$ incubations $\left(270 \mathrm{nmol} \mathrm{cm}{ }^{-3}{ }^{15} \mathrm{~N}\right.$ nitrate added) was $5.2 \%$ for Stn $\mathrm{H}$ and $1.3 \%$ for Stn $\mathrm{L}$. Similar proportions were obtained when $27 \mathrm{nmol} \mathrm{cm} \mathrm{cm}^{-3}$ ${ }^{15} \mathrm{~N}$-nitrate was added and therefore the recovered amount of ${ }^{15} \mathrm{~N}$-ammonium was 10 times higher with a 10 -fold addition of ${ }^{15} \mathrm{~N}$-nitrate (Table 3).

Table 3. Depth distribution at Stn $\mathrm{H}$ of recovered ${ }^{15} \mathrm{~N}$ ammonium after $6 \mathrm{~h}$ incubation with 27 and $270 \mathrm{nmol} \mathrm{cm}{ }^{-3}$ of ${ }^{15} \mathrm{~N}-\mathrm{NO}_{3}^{-}$

\begin{tabular}{|ccccc|}
\hline $\begin{array}{c}\text { Depth } \\
\text { (cm) }\end{array}$ & \multicolumn{5}{c}{${ }^{15} \mathrm{~N}_{\text {recovered as } \mathrm{NH}_{4}^{+}}$} \\
& 27 & 270 & 27 & 270 \\
\hline & & & 27 & \\
& & & & \\
& & & & \\
$0-2$ & 0.7 & 6.4 & 2.6 & 2.4 \\
$2-4$ & 0.9 & 11.9 & 3.3 & 4.4 \\
$6-8$ & 2.2 & 20.0 & 8.2 & 7.4 \\
$8-10$ & 1.6 & 27.7 & 5.9 & 10.3 \\
\hline
\end{tabular}

\section{DISCUSSION}

The sampled stations are likely to be representative of the coastal waters of southwest Scandinavia because the organic carbon and nitrogen contents and $\mathrm{C} / \mathrm{N}$ versus depth relation were comparable with those reported by Blackburn \& Henriksen (1983). A thorough 
study of the benthic macro-fauna in Skagerrak, including the inshore areas and $\mathrm{Stn} \mathrm{H}$, was presented by Josefson (1985). The macro-fauna biomass in our cores was typical for many of the coastal sediments at 20 to $50 \mathrm{~m}$ as presented by Josefson (1985). We found relatively low numbers of Amphiura filiformis at both stations but our numbers obtained at Stn $\mathrm{H}$ agreed with those given by Josefson (1985).

\section{Nitrification and nitrate consumption}

The estimated nitrification rate of $250 \mu \mathrm{mol} \mathrm{m}^{-2} \mathrm{~h}^{-1}$ at Stn $\mathrm{L}$ was higher than the rates measured by Henriksen et al. (1981) in the Skagerrak and Kattegat and by most other workers. The rates were in the same range, however, as those reported by Billen (1976) for the North Sea coast and similar to the maximum rates reported by Hansen et al. (1981) in the Kysing fjord, Denmark. Although there are a number of uncertainties concerning the methodology, as discussed by Somville (1978), Glover (1985) and Enoksson (1986), this rough estimate is comparable (within a factor of 2 ) with the predicted rate of nitrogen regeneration anticipated from benthic oxygen consumption during 'Redfield decomposition'. The demonstrated nitrifying activity in the upper $2 \mathrm{~cm}$ was also reflected in the peaks of nitrate in situ (Fig. 1B). Although our estimate of the nitrification rate is comparatively high, there are strong arguments why this sediment should be an environment that favours nitrifying bacteria. Amphiura filiformis is known to contribute to the oxygenation of the upper layers (Ockelmann \& Muus 1978) and as Amphiura spp. consist largely of $\mathrm{CaCO}_{3}$ they may, dead or alive, be an important substrate for nitrifiers. This is plausible because the acid produced by these bacteria may dissolve the carbonate which therefore acts both as a pH-buffer and a source of bicarbonate for growth of the autotrophic nitrifiers.

The steady state turnover time of the nitrate pool at Stn L (Fig. 1B) at the estimated nitrification rate would be less than $1 \mathrm{~h}$ in the upper $1 \mathrm{~cm}$. In spite of the rapid nitrification, sediments from Stn $\mathrm{L}$ removed nitrate from the water at the highest rates observed in this study (Table 2). These observations indicate that there was not only a high rate of nitrification at Stn $\mathrm{L}$ but also an even higher rate of nitrate consumption within the sediment. Ammonium may act as an inhibitor of assimilatory nitrate reduction (Payne 1973), and because ammonium was present (Fig. 1A), it was assumed that the added nitrate was consumed in dissimilatory pathways and that none or very little was assimilated. A potential for DAP was demonstrated at all depths in the sediments from both stations. Less than $10.3 \%$ of the consumed nitrate- $\mathrm{N}$ was, however, found in the ammonium pool (Table 3). Denitrification in this study thus seems to have amounted to more than $90 \%$ of the total nitrate consumption. This is comparable with the 70 to $95 \%$ of total nitrate consumption in several sediment types, which included mud, marsh, sand and eelgrass bed (Kaspar 1983). In an estuarine sediment with a high level of organic carbon $(7.4 \%)$, DAP was responsible for 15 to $28 \%$ of the total nitrate consumption (Buresh \& Patrick 1981). In our study, the organic carbon content was low (1.5 to $3.0 \%$ in the upper layers) and the results are consistent with the hypothesis that denitrification dominates in systems with low organic levels (Kaspar et al. 1981). The turnover of the ammonium pool may not have significantly affected the results, unless unreasonably high ammonium regeneration rates were assumed. A more pertinent error might have been the possibly selective stimulation of the denitrifying bacteria by the extra addition of nitrate (King \& Nedwell 1985).

The fact that DAP did occur in the upper $1 \mathrm{~cm}$ (Fig. 4) was not surprising because nitrate was provided (Fig. 1B) and because there are anoxic sites within the upper few $\mathrm{mm}$ (Revsbech et al. 1980). At Stn L in our study, the coexistence of nitrification and DAP was proven. The relatively low capacity for DAP in the upper layers (Fig. 4) indicates that denitrifiers were more successful in the competition for nitrate. From the results in Table 3, it seems feasible to conclude that the dissimilatory nitrate reduction to ammonium was nitrate limited in these sediments at all depths. Nitrification within the sediment was by far the main source of nitrate within the sediment-water system. Assuming a steady state situation, DAP was calculated for Stn L from the nitrification rate and the measured fractions of nitrate which were reduced to ammonium. This yielded an in situ DAP value of $1.2 \mu \mathrm{mol} \mathrm{m} \mathrm{m}^{-2} \mathrm{~h}^{-1}$ and a maximum rate of $0.05 \mathrm{nmol} \mathrm{cm}^{-3} \mathrm{~h}^{-1}$ in the upper $2 \mathrm{~cm}$. Nitrification activity was not demonstrated below a depth of $2 \mathrm{~cm}$ and nitrate was provided only by diffusive transport to and bioturbation of the deeper layers of the sediment. The relatively high capacity for DAP found in deeper layers was most likely due to the potential activity of bacteria which are normally subjected only to trace concentrations of nitrate and nitrite and not representative of in situ activity. Consequently, their contribution to the total DAP was probably subordinate. Sørensen (1978) suggested that these types of bacteria are fermentative with a capacity to reduce nitrate to ammonium.

\section{Flux measurements}

Rates of oxygen consumption and ammonium release (Table 2) are comparable to other data 
obtained in the same area (e.g. Enoksson \& RüdénBerg 1983, Anderson et al. 1986). If the organic material in the present sediment with a $\mathrm{C} / \mathrm{N}$ ratio of about 10.5 (Table 1) was mineralized according to Redfield et al. (1963), one would expect the regeneration of approximately $1 \mu \mathrm{mol} \mathrm{m} \mathrm{m}^{-2}$ of ammonium following the consumption of $10 \mu \mathrm{mol} \mathrm{m} \mathrm{m}^{-2}$ of oxygen gas provided that no nitrification occurred. Only slightly more oxygen would be consumed per mineralized nitrogen if this nitrogen was subsequently nitrified and denitrified. This is because mineralization would partly be based on denitrification. Fig. 2 shows that it was not possible to use the 'Redfield decomposition model' for predicting the release of inorganic nitrogen (IN) from the sediment; on the contrary, in some of the cores there was an uptake of IN by the sediment in the oxygen consumption range of 600 to $1000 \mathrm{umol}$ $\mathrm{m}^{-2} \mathrm{~h}^{-1}$. The rate of ammonium release approximated the predicted values in cores with low oxygen concentration (Group a) in the overlying water. The fact that mainly ammonium was released in these cores indicated that nitrification was oxygen limited and that ammonium was actually regenerated. Dissolved organic nitrogen (DON) was released from the Stn $\mathrm{H}$ cores at a reasonably constant rate of approximately $24 \mu \mathrm{mol} \mathrm{m}^{-2} \mathrm{~h}^{-1}$. It was therefore feasible that the 'missing' IN was not substituted by DON release. It is assumed that higher amounts of ammonium were excreted by the fauna in the cores with the richest macro-fauna (Fig. 2, Group c). Contrary to what would be expected, the release of IN to the water was within about the same range irrespective of the macro-fauna. This was partially due to the nitrate uptake in cores with the highest numbers of Amphiura spp. Obviously the number of Amphiura spp. was of greater importance for the nitrate uptake than was the nitrate concentration in the overlying water. Therefore, we believe that Amphiura spp. (the dominant macro-fauna) belong to the group of infauna which decreases the IN efflux by enhancing nitrate respiration in the burrows or in its feces (Sayama \& Kurihara 1983). Nitrate uptake from the overlying water explained, however, only a minor part of the anticipated 'loss' of IN. It seems plausible to explain these findings by either one or both of 2 hypotheses: (1) Non-steady-state conditions with ammonium accumulation and/or incorporation of nitrogen into the bacteria during their growth on a high $\mathrm{C} / \mathrm{N}$ ratio substrate, as discussed by Blackburn \& Henriksen (1983); (2) Steady-state conditions with coupled nitrification-denitrification as a nitrogen sink. In this study, the $C / N$ ratio of the substrate actually utilized by the microbes was not known. Blackburn \& Henriksen (1983) reported ratios generally below 15 and did not measure a net ammonium uptake in the uppermost sediment layer. Because the estimated ni- trification rate at Stn L (Fig. 3) was in the same range (actually greater by a factor of 2) as the rate of IN 'loss' and because only a small fraction of the nitrate was again reduced to ammonium, nitrification-denitrification was most probably responsible for the 'missing' IN release. Low $\mathrm{IN} /-\mathrm{O}_{2}$ ratios have previously been reported by Nixon et al. (1976) for bioturbated sediments and by Boynton \& Kemp (1985) and in both these reports the same conclusion was drawn.

Dissimilatory ammonium production contributed a minor role $(0.5 \%$ at $\operatorname{Stn} \mathrm{L}, 0$ to $2 \mathrm{~cm})$ when compared with the assumed denitrification. The reasons for this might have been the low organic carbon level and relatively oxidized conditions. Emerson et al. (1985) reported that bioturbation was responsible for the downward transport of freshly settled organic material and this mechanism could probably explain the remarkable homogeneity in organic carbon and nitrogen with depth at both stations (Table 1). In addition, animals most likely stimulated nitrifying activity to at least $2 \mathrm{~cm}$ depth (Fig. 3). The nitrate reducers were thus provided with both nitrate and a carbon source. Assuming steady-state conditions, at Stn L $1.3 \mu \mathrm{mol}$ $\mathrm{m}^{-2} \mathrm{~h}^{-1}$ of the nitrate, (supplied both from nitrification [250 $\mu \mathrm{mol} \mathrm{m}^{-2} \mathrm{~h}^{-1}$ ] and from the overlying water [24 $\mu \mathrm{mol} \mathrm{m}{ }^{-2} \mathrm{~h}^{-1}$ ]) was recycled to ammonium through a dissimilatory reduction while the remaining $99.5 \%$ presumably was denitrified.

Acknowledgements. We thank Patricia Conway, Staffan Kjelleberg, Birgitta Norkrans, Ulf Rönner, and Fred Sörensson for valuable discussions of results and the manuscript. We also thank Solvi Billing and Lena Rüdén for excellent technical assistance and Lars Brändström for rebuilding the flowthrough incubator. This work was supported by grants from the National Swedish Environment Protection Board.

\section{LITERATURE CITED}

Aller, R. C. (1980). Quantifying solute distributions in the bioturbated zone of marine sediments by defining an average microenvironment. Geochim. cosmochim. Acta 44: 1955-1965

Anderson, L. G., Hall, P. O. J., Iverfeldt, Å., Rutgers van der Loeff, M. M., Sundby, B., Westerlund, S. F. G. (1986). Benthic respiration measured by total carbonate production. Limnol. Oceanogr. 31. 319-329

Armstrong, F. A. J., Williams, P. M., Strickland, J. D. H. (1966). Photo-oxidation of organic matter in sea water by ultraviolet radiation, analytical and other applications. Nature, Lond. 211: 481-483

Armstrong, F. A. J., Stern, C. R., Strickland, J. D. H. (1967). The measurement of upwelling and subsequent biological processes by means of the Technicon Auto-Analyzer and associated equipment. Deep Sea Res. 14: 381-389

Billen, G. (1976). Evaluation of nitrifying activity in sediments by dark ${ }^{14} \mathrm{C}$-bicarbonate incorporation. Wat. Res. 10 : $51-57$

Blackburn, T. H. (1979). Method for measuring rates of $\mathrm{NH}_{4}^{+}$ 
turnover in anoxic marine sediments, using a ${ }^{15} \mathrm{~N}-\mathrm{NH}_{4}^{+}$ dilution technique. Appl. environ. Microbiol. 37: 760-765

Blackburn, T. H., Henriksen, K. (1983). Nitrogen cycling in different types of sediments from Danish waters. Limnol. Oceanogr. 28: 477-493

Boynton, W R., Kemp, W. M. (1985). Nutrient regeneration and oxygen consumption by sediments along an estuarine salinity gradient. Mar. Ecol. Prog. Ser. 23: 45-55

Buresh, R. J., Patrick, Jr., W. H. (1981). Nitrate reduction to ammonium and organic nitrogen in an estuarine sediment. Soil Biol. Biochem. 13: 279-283

Emerson, S., Fischer, K., Reimers, C., Heggie, D. (1985). Organic carbon dynamics and preservation in deep-sea sediments. Deep Sea Res. 32: 1-21

Enoksson, V. (1986). Nitrification rates in the Baltic Sea: Comparison of three isotope techniques. Appl. environ. Microbiol. 51: 244-250

Enoksson, V., Rüdén-Berg, L. (1983). A system for determining exchanges between sediment and water exemplified by nitrogen flux under controlled oxygen conditions. In: Hallberg, R. (ed.) Ecol. Bull. Vol. 35, Environmental biogeochemistry. Publishing House/FRN, Stockholm, p. 243-250

Glover, H. E. (1985). The relationship between inorganic nitrogen oxidation and organic carbon production in batch and chemostat cultures of marine nitrifying bacteria. Arch. Microbiol. 142: 45-50

Hansen, J. I., Henriksen, K., Blackburn, T. H. (1981). Seasonal distribution of nitrifying bacteria and rates of nitrification in coastal marine sediments. Microb. Ecol. 7: 297-304

Hedges, J. I., Stern, J. H. (1984). Carbon and nitrogen determinations of carbonate-containing solids. Limnol. Oceanogr. 29: 657-663

Henriksen, K., Hansen, J. I., Blackburn, T. H. (1981). Rates of nitrification, distribution of nitrifying bacteria, and nitrate fluxes in different types of sediment from Danish waters. Mar. Biol. 61: 299-304

Henriksen, K., Rasmussen, M. B., Jensen, A. (1983). Effect of bioturbation and microbial nitrogen transformations in the sediment and fluxes of ammonium and nitrate to the overlaying water. In: Hallberg, R. (ed.) Ecol. Bull. Vol. 35, Environmental biogeochemistry. Publishing House/FRN, Stockholm, p. 193-205

Jenkins, M. C., Kemp, W. M. (1984). The coupling of nitrification and denitrification in two estuarine sediments. Limnol. Oceanogr. 29: 609-619

Josefson, A. (1985). Spatial and temporal structure of marine infauna in the Skagerrak (Eastern North Sea). Ph. D. thesis, Univ, of Göteborg

Jørgensen, B. B. (1978). A comparison of methods for the quantification of bacterial sulfate reduction in coastal marine sediments. Geomicrob. J. 1: 11-27

Kaspar, H. F. (1983). Denitrification, nitrate reduction to ammonium, and inorganic nitrogen pools in intertidal sediments. Mar. Biol. 74: 133-139
Kaspar, H. F., Tiedje, J. M., Firestone, R. B. (1981). Denitrification and dissimilatory nitrate reduction to ammonium in digested sludge. Can. J. Microbiol. 27: 878-885

King, D., Nedwell, D. B. (1985). The influence of nitrate concentration upon the end-products of nitrate dissimilation by bacteria in anaerobic salt marsh sediment. FEMS Microbiol. Ecol. 31: 23-28

Koike, I., Hattori, A. (1978). Denitrification and ammonia formation in anaerobic coastal sediments. Appl. environ. Microbiol. 35: 278-282

Koroleff, F. (1976). Determination of ammonia. In: Grasshoff, K. (ed.) Methods of seawater analysis. Verlag Chemie, Weinheim, p. 126-133

Nixon, S. W., Oviatt, C. A., Hale, S. S. (1976). Nitrogen regeneration and the metabolism of coastal marine bottom communities. In: Andersson, J. M., MacFayden, A. (ed.) The role of terrestrial and aquatic organisms in decomposition processes. Blackwell Scientific Publ., Oxford, p. $269-283$

Ockelmann, K. W., Muus, K. (1978). The biology, ecology and behaviour of the bivalve Mysella bidentata (Montagu). Ophelia 17: 1-93

Payne, W. J. (1973). Reduction of nitrogenous oxides by microorganisms. Bact. Rev. 37: 409-452

Redfield, A. C., Ketchum, B., Richards, F. A. (1963). The influence of organisms on the composition of seawater. In: Hill, M. N. (ed.) The sea, Vol. 2. Interscience Publishers, New York, p. 26-77

Revsbech, N. P., Sorensen, J., Blackburn, T. H. (1980). Distribution of oxygen in marine sediments measured with microelectrodes. Limnol. Oceanogr. 25: 403-411

Samuelsson, M.-O. (1985). Dissimilatory nitrate reduction to nitrite, nitrous oxide, and ammonium by Pseudomonas putrefaciens. Appl. environ. Microbiol. 50: 812-815

Samuelsson, M.-O., Rönner, U. (1982). Ammonium production by dissimilatory nitrate reducers isolated from Baltic sea water, as indicated by ${ }^{15} \mathrm{~N}$ study. Appl. environ. Microbiol. 44: 1241-1243

Sayama, M., Kurihara, Y. (1983). Relationship between burrowing activity of the polychaetous annelid, Neanthes japonica (Izuka) and nitrification-denitrification processes in the sediments. J. exp. mar. Biol. Ecol. 72: 233-241

Smith, D. W., Fliermans, C. B., Brock, T. D. (1972). Technique for measuring ${ }^{14} \mathrm{CO}_{2}$ uptake by soil microorganisms in situ. Appl. environ. Microbiol 23: 595-600

Somville, M. (1978). A method for the measurement of nitrification rates in water. Wat. Res. 12: 843-848

Strickland, J. D. H., Parsons, T. R. (1972). A practical handbook of sea water analysis. Bull. Fish. Res. Bd Can. 167

Sørensen, J. (1978). Capacity for denitrification and reduction of nitrate to ammonia in a coastal marine sediment. Appl. environ. Microbiol. 35: 301-305

Valderrama, J. C. (1981). The simultaneous analysis of total nitrogen and total phosphorus in natural waters. Mar. Chem. 10: 109-122 